\title{
Innovative financing of creative projects on the Kickstarter platform: Ukrainian and Polish experience
}

\author{
Iuliia Gernego ${ }^{1, *}$, Liudmyla Petrenko ${ }^{2}$, Mykhailo Dyba ${ }^{1}$, and Vitalii Tsarov ${ }^{2}$ \\ ${ }^{1}$ Kyiv National Economic University named after Vadym Hetman, Corporate Finance and Controlling Department, 54/1 Peremohy Ave., \\ Kyiv, 03057, Ukraine \\ ${ }^{2}$ Kyiv National Economic University named after Vadym Hetman, Business Economics and Entrepreneurship Department, 54/1 \\ Peremohy Ave., Kyiv, 03057, Ukraine
}

\begin{abstract}
In the era of digital economy, the crowdfunding platforms provide the background to mitigate cross-country differences within project financing. In particular, creative projects are important as a vital driver in maintaining business and social sector competitive. Thereby, research problem lays upon the potential of providing crowdfunding support to overcome the creative project divide in different countries. The paper aims to provide scientific support on creative projects innovative financing in Ukraine and Poland within Kickstarter. The research methodology is based on Kickstarter data (10 years; 83 industries and 898 projects) processed by statistical analysis. The Concentration Ratio (CR) was modified to measure the concentration of efforts, considering the largest creative industries within Kickstarter platform. The results section represents high rates of concentration of efforts for Ukrainian creative projects that commercialize tangible physical goods: Product Design and Gadgets. At the same time, in Poland the main concentration of efforts is in the field of intangible intellectual products: Tabletop Games and Video Games. Thus, digital platform is a reflection of interrelations between intangible and tangible values in economies. The study results can be used within national programs of creative innovative projects financial support. In relation to other countries, more extensive study is required.
\end{abstract}

\section{Introduction}

\subsection{Research question}

In the new global economy, creative projects have become an important part of successful innovative entrepreneurship, coming with new ways to meet both economic, cultural and social challenges. Human development projects influence both the modern business and society, transforming standard of living, working conditions within industries, education, cultural and health systems. The success of a few start-ups that started to take care of factors of creative industries development makes up the need to replace some resources as the companies tend to meet new challenges, enhancing their activity into new markets. However, in many cases, the issue of failed human development projects, including creative ones, is mostly related to insufficient funding $[1 ; 2]$. For instance, the annually efforts to meet sustainable development goals (SDGs) are estimated to cost about $4.5 \mathrm{tn}$. USD, including $2 \mathrm{tn}$. USD for cultural and creative industries development, that makes more than US federal budget [3]

Thereby, determining the impacts of innovative financial resources and mechanisms is becoming more crucial than ever before for the future of creative industries worldwide. In particular, there is already some evidence on crowdfunding and its influence on creative project development. Due to the practical experience, the crowdfunding mechanism is able to overcome many human development challenges and direct more funds to satisfy the most urgent social, economic, cultural and environmental needs. The particular interest should be paid to particular crowdfunding platforms such as GlobalGiving, Indiegogo and Kickstarter, which raise annually about 34 bn. USD within the global crowdfunding industry [3].

Studies have found positive linkages between human development and creative industries development trends and access to crowdfunding services (e.g. D. C. Brabham [4] and B. Boeuf, J. Darveau, R. Legoux [5] on crowdfunding financing of cultural component; M. G. Colombo, C. Franzoni, C. Rossi-Lamastra on crowdfunding influence on human capital and education [6]; M. Farnel 2015 on crowdfunding role to solve health and cultural challenges [7]), although the quality of crowdfunding services provided has been questioned (e.g. M. Barbi, M. Bigelli [8] and J. H. Ganatra [9]).

In light of recent trends of crowdfunding, it is more difficult to find studies that provide a comparative analysis of crowdfunding effectiveness indicators, considering the relation between crowdfunding financing and successful creative projects implementation in particular countries. Thus, the current study tends to

\footnotetext{
* Corresponding author: iuliiagern@ukr.net
} 
highlight the tendencies of creative projects crowdfunding financing, using the data of two neighboring countries, namely Poland and Ukraine. At the analytical part of the research, attention is paid to the creative projects of the above-mentioned countries crowdfunding financing on Kickstarter, which is one of the leading crowdfunding platforms globally. The genesis of this thesis can be traced back to the time the authors became interested in innovative sources of social and economic development financial support in Ukraine and abroad.

\subsection{Previous researches}

Several previous studies and international organizations reports have found that crowdfunding has a significant potential to support creative industries worldwide by boosting innovation in the creative sector, generating wealth and social growth [4-10].

More recently, literature has emerged that offers findings of the relationship between the trends of financing and creative industries development at the national or cross-country level, largely with a focus on the health and educational components. In particular, some researchers have found an association between education and health sectors financing and improvements in both access to these services and related creative industries development outcomes [13, 14], considering the possibility and potential effect of innovative financing across national economies. Other studies pay attention to different social and economic sectors financing $[11,12]$, considering the possibility to achieve both social and economic progress.

Particularly, in the literature on innovative sources of creative project financing, the relative importance of crowdfunding essence has been subject to considerable discussion. Even though crowd co-financing relates to the previous centuries, it is defined as an innovative paradigm within the scientific concept nowadays.

According to G. Le Bon, "While all our ancient beliefs are tottering and disappearing, while the old pillars of society are giving way one by one, the power of the crowd is the only force that nothing menaces, and of which the prestige is continually on the increase. The age we are about to enter will in truth be the era of crowds" [15]. Since the late 1990s collective efforts of individuals who network and pool their resources, usually via the Internet, to support the efforts initiated by other people or organizations are defined as crowdfunding [16;17].

For instance, Hengchen, and Zhang are paying attention to the reward-based crowdfunding concept, when crowdfunding aims to increase the capital volume from potential consumers to reach a measure of social and economic goals [18]. Kindler, Golosovsky, and Sorin define crowdfunding among the emerging channels for spreading social collective action and funding of novelty in all these domains, considering the potential of various crowdfunding platforms. In particular, these experts pay attention to the lack of experience on Kickstarter, Indiegogo and Sellaband mechanism of data collection [19]. Dahlhausen et all continue researches about the crowdfunding potential to support creative projects that are funded by the masses through websites such as Kickstarter and Indiegogo. Thereby, these crowdfunding platforms are becoming popular both within theoretical researches and practice that has been steadily gaining attention in the last few years, across many different sectors of society [20].

In particular, nearly 5 bn USD are collected from nearly $5 \mathrm{mln}$. backers on Kickstarter yearly, which are divided within about 200 thousand successful funded projects [3]. In light of recent trends of digital society growth and increase the number of funding projects that have reached their goals, Kickstarter becomes an important source for creative industries financing globally. Also, following the Web of Science Core Collection report, the total publication volume on Kickstarter topic is increasing since 2000. In particular, the highest increase has taken place within the last 5 years. Thus, the chosen problem is of a significant scientific interest nowadays.

\subsection{The scientific problem}

The scientific problem of this article lays upon the potential of providing flexible crowdfunding support to overcome the social and economic divide in order to improve the creative sector environment in Ukraine and Poland. The hypothesis of the paper has both theoretical and applied background, concerning the crowdfunding impact on human development process and innovative sources of financial support, which aims to activate innovative creative projects implementation. The aim of the current study is to identify similarities and differences, discover the best practices and present how the modern innovative creative projects are crowdfunded in Ukraine and Poland, based on Kickstarter statistic. The object of the research is crowdfunding boost within two neighboring countries. The subject is creative projects development financing volumes on Kickstarter, contributing the social and economic growth within both countries.

\subsection{The research methodology}

The research methodology is based on Kickstarter data processed by statistical analysis. Data on crowdfunding in various types of projects were collected by authors directly from Kickstarter. A time period of research is 10 years: $2009-2019$; the number of industries: 83 ; the number of projects: 898. Total funds raised by researched Polish projects are 24993092 \$; by Ukrainian projects are 5046334 \$. During the analysis, the following data were studied: Industry, stated goal (\$), Raised funds (\$), Reaching the goal (\%), Total funds raised (\$), Max. successful project (\$).

A higher concentration of efforts allows players to maximize the likely financial result while expanding efforts is designed to reduce the risks of failure. For measuring concentration of efforts, the Concentration Ratio (CR), proposed by Bain to analyze the market 
share, was used [21]. The scientific novelty of the methodology is as follows: in the study, the Concentration Ratio (CR) is applied with the following modifications: 1) not the share of the largest firms in industry revenue, but the share of the largest industries in the general market; 2) not a market for products, but a market for resources (namely, crowdfunding financing). The Three-Branch Concentration Ratio / The TenBranch Concentration Ratio measures the total market share of the three / ten largest industries on the Kickstarter platform accordingly.

\subsection{The current research structure}

The current research consists of the following parts:

- primarily, a theoretical framework based on innovative sources of creative projects financing and crowdfunding definition is provided;

- secondly, the Kickstarter phenomenon is described; the placement of Ukrainian and Polish creative projects on a crowdfunding platform is analyzed; the authorial approach of efforts concentration for crowdfunding financing is represented (Ukrainian and Polish Kickstarter experience);

- then, the research conclusions on crowdfunding effectiveness for creative industries development in Ukraine and Poland are provided.

The research practical implication is that results can be used within national innovative financial support strategies to accept community challenges both on national and regional levels.

\section{Main theoretical assumptions of the research}

\subsection{Innovative sources for creative projects financing}

In the context of the current activity of economic entities, there is an interaction between the traditional components of the chain of production resources, namely "human resources - material resources - financial resources". However, the goals and objectives of economic and cultural development, the strategic importance of each component is changing, depending on the environment [22, p. 139]. The primary requirement for innovative activity within social, economic and creative sectors means qualitative changes of human and financial resources.

Thereby, the improvement of the qualitative characteristics of human resources creates the basis for scientific, cultural and technical development, innovative social and economic initiatives creation, innovative projects implementation and innovative characteristics of creative industries development within the national economy. At the same time, sufficient and systematic funding is needed to expand the range of human and material resources. Following the above-mentioned information, fundraising allows to systematize the process of financial resources attraction and diversify the sources of their attraction.

Despite traditional resources of creative projects, financing that involves attracting the resources of economic entities, state budget resources and foreign investors; fundraising involves the use of both "real" and "virtual" resources. Thus, resources and opportunities of national economic entities, financial institutions, the state, and foreign investors are expanded due to the digital technologies widespread (Figure 1).

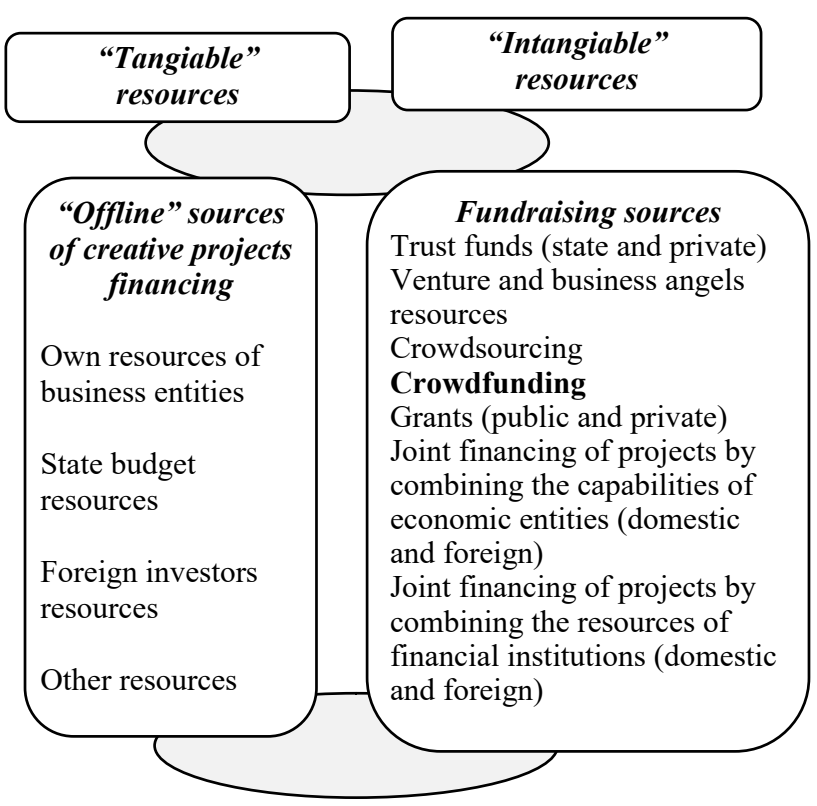

Fig. 1. Fundraising and opportunities for creative projects financing

Direct mailing, crowdsourcing (obtaining the necessary services through the fulfillment of socially important tasks by a multitude of volunteers coordinating activities through information technology) and crowdfunding (the process of voluntarily cooperation of entities who provide financial or other kind of assistance to solve particular social challenges through Internet), virtual negotiations are considered in the context of online and email fundraising [23, p. 279].

This proves the potential for attracting alternative private resources to achieve the goals of sustainable human development and creative industries growth.

\subsection{Theoretical framework of crowdfunding}

In the context of substantiating the potential of innovative financial mechanisms to ensure creative project implementation in Ukraine and Poland, the attention should be paid to the widespread of Internet technologies to all areas of human life, including cultural ones. In particular, the rapid development of information technology is transforming how people use, shape, and disseminate educational and cultural content, their ideas, participating in social life.

International organizations tend to pay attention to the measure of key indicators of competitiveness of the national economy, including the potential to create 
innovation and improve living standards, taking into account the level of scientific and technological development, infrastructure and financial market trends [24]. This is associated with the rapid development of the Internet environment, which forms the so-named "online" infrastructure. Transition to the information society causes structural changes in an aggregate capital to provide social benefits. The volumes of "intangible" financial resources are rapidly growing. Thus, fundraising online sources are becoming globally widespread.

In particular, the crowd technologies concept has received considerable critical attention within the modern socially-oriented society. The term "crowd", which means common efforts to provide financial support for creative projects, is at the heart of our understanding of crowd technologies. The mentioned technologies are representing a mechanism of a wide range of stakeholders' online cooperation to meet urgent social and economic challenges [25, p. 426].

Thereby, the crowd technologies represent a major area of interest within the field of innovative social and economic changes financing. At the same time, there is a wide range of crowd technologies diversity within the international practice of creative projects financial support (Figure 2).

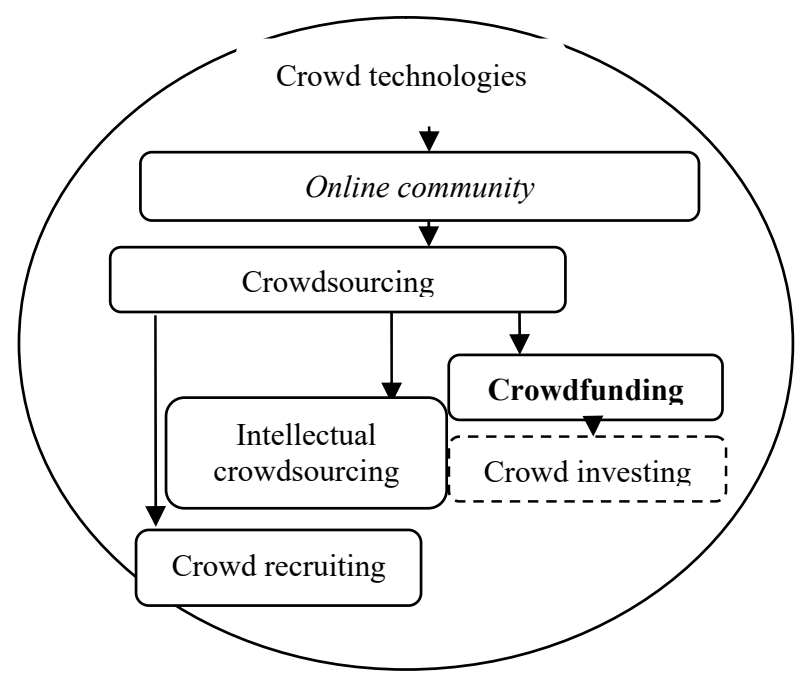

Fig. 2. Crowd technologies spectrum

Crowd technologies can play an important role in addressing the issue of a virtual community. Reingold defines the virtual community as a social-oriented network that involves the support of a large group of people in open discussion to achieve specific goals [27]. To commercialize virtual community capabilities, it is advisable to use crowdsourcing capabilities, which characterize opportunities to attract the necessary resources through the Internet. For instance, Eric von Hippel examined the impact of crowdsourcing into a user-friendly innovation. Thus, the crowd technology development depends on the growing demand for social investment within modern society.

In particular, intellectual crowdsourcing technologies involve the intellectual collaboration of particular individual knowledge and skills through social networks.
Such common interaction aims to create an intellectual product, integrating the knowledge and skills of a significant number of people ("crowd"). At the same time, intellectual interconnections have no territorial, corporate, professional, social and cultural barriers due to their online widespread [28; 29]. However, the theoretical and applied evidence shows the possibility to attract additional human resources through the Internet (crowd recruiting technologies).

At the same time, modern studies have provided evidence on the growing influence of sustainable financing into creative project implementation through the crowdfunding mechanism. The theoretical considerations provide the concept of crowdfunding that is defined as a combination of the terms crowd and funding. However, the crowdfunding process has mostly practical applications. Thereby, the crowdfunding influence on creative project development should be evaluated as the result of specific crowdfunding projects implementation. The essence of crowdfunding may be defined as "worldwide financing", "a social bank", "a collective wallet", "public financing", "common fold". The current study aims to test the creative projects' successful implementation through an innovative mechanism of crowdfunding platform functionality.

\section{Research results}

\subsection{Global crowdfunding market trends}

Crowdfunding platforms are considered as major drivers for social and economic development worldwide. By Statista data, total transaction value in the crowdfunding segment amounts to \$6,923.6 mln in 2019 (Figure 3).

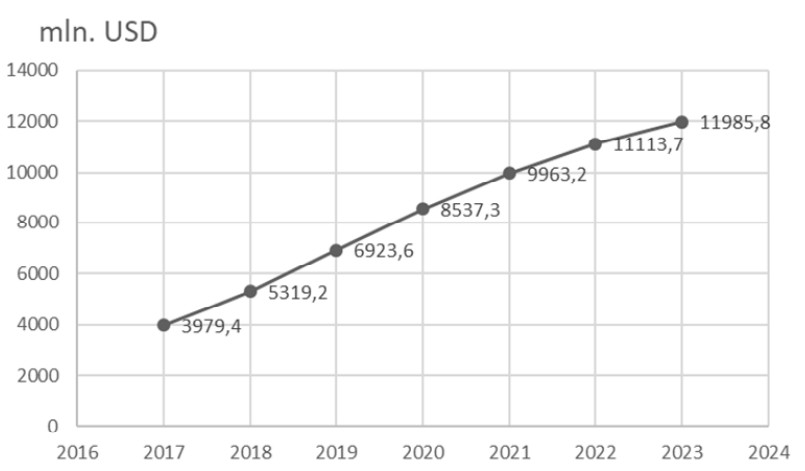

Fig. 3. Global crowdfunding trends (based on Statista [30])

Another important practical implication is that the top crowdfunding platforms play an important role within social and economic development within particular economies. Thereby, this particular research finding points to the need for the leading crowdfunding platforms functionality analysis (Table 2).

Under Statista data, the quantity of crowdfunding campaigns tends to be about 8724 thousand in 2019 . At the same time, the number of funding campaigns in the crowdfunding segment is expected to amount to 12,063.9 thousand by 2023 [30] (Figure 4). 
Table 2. Top 10 crowdfunding platforms worldwide.

\begin{tabular}{|c|c|c|}
\hline $\begin{array}{l}\text { Crowd- } \\
\text { funding plat- } \\
\text { form }\end{array}$ & Main characteristics & $\begin{array}{l}\text { Core areas } \\
\text { of financing }\end{array}$ \\
\hline Kickstarter & $\begin{array}{l}\text { The crowdfunding platform is } \\
\text { known as one of the most popular } \\
\text { worldwide. The initiative has } \\
\text { raised over } \$ 4.5 \text { billion with more } \\
\text { than } 170000 \text { projects funded sin- } \\
\text { ce its inception in 2009. Cate- } \\
\text { gories include Arts, Comics \& } \\
\text { Illustration, Design \& Tech, Film, } \\
\text { Food \& Craft, Games, Music, and } \\
\text { Publishing. Kickstarter is an all or } \\
\text { nothing platform, which means } \\
\text { that you don't get your funds } \\
\text { unless you complete your } \\
\text { campaign. Kickstarter mainly } \\
\text { provides financing to assist } \\
\text { within social, high- technology } \\
\text { and creative business } \\
\text { development }\end{array}$ & $\begin{array}{l}\text { Tech and } \\
\text { creative en- } \\
\text { trepreneurs, } \\
\text { venture busi- } \\
\text { ness, social } \\
\text { business, in- } \\
\text { ventions }\end{array}$ \\
\hline Indiegogo & $\begin{array}{l}\text { The crowdfunding platform aims } \\
\text { to provide assistance within the } \\
\text { process of non-profit business } \\
\text { activity. The crowdfunding } \\
\text { platform works similarly to Kick- } \\
\text { starter, except it doesn't have an } \\
\text { exclusively all or nothing fund- } \\
\text { raising model. }\end{array}$ & $\begin{array}{l}\text { Social initia- } \\
\text { tives }\end{array}$ \\
\hline Patreon & $\begin{array}{l}\text { Patreon is a monthly subscription } \\
\text { platform where supporters and } \\
\text { donors provide regular monthly } \\
\text { contributions, rather than one } \\
\text { bulk payment. }\end{array}$ & $\begin{array}{l}\text { Creative ven- } \\
\text { ture or artist }\end{array}$ \\
\hline GoFundMe & $\begin{array}{l}\text { The crowdfunding site collects a } \\
2.9 \% \text { processing fee and } 30 \text { cents } \\
\text { for every donation. }\end{array}$ & \begin{tabular}{|l|} 
Short-term \\
personal pro- \\
jects
\end{tabular} \\
\hline Crowdrise & $\begin{array}{l}\text { Crowdrise is geared more toward } \\
\text { helping "real-world issues", } \\
\text { rather than funding for-profit } \\
\text { ventures. }\end{array}$ & $\begin{array}{l}\text { Cycling and } \\
\text { walking } \\
\text { events, non- } \\
\text { profit event } \\
\text { fundraising, } \\
\text { and online } \\
\text { social fund- } \\
\text { raising } \\
\end{array}$ \\
\hline PledgeMusic & $\begin{array}{l}\text { You can provide rewards for do- } \\
\text { nors who pledge a certain level, } \\
\text { such as downloadable digital } \\
\text { music. }\end{array}$ & $\begin{array}{l}\text { Music and } \\
\text { musicians de- } \\
\text { velopment }\end{array}$ \\
\hline MightyCause & $\begin{array}{l}\text { Financial support for special } \\
\text { events for children and family, } \\
\text { education, animals and pets, and } \\
\text { even faith-based causes. }\end{array}$ & $\begin{array}{l}\text { "Worthy cau- } \\
\text { ses" }\end{array}$ \\
\hline InKind & $\begin{array}{l}\text { The financial assistance is provi- } \\
\text { ded to support restaurant business } \\
\text { representatives }\end{array}$ & $\begin{array}{l}\text { Restaurant } \\
\text { business }\end{array}$ \\
\hline Crowdfunder & $\begin{array}{l}\text { The platform pay angel investor } \\
\text { or venture capitalist attention to } \\
\text { particular projects }\end{array}$ & $\begin{array}{ll}\text { Venture, in- } \\
\text { novative ini- } \\
\text { tiatives }\end{array}$ \\
\hline Give & $\begin{array}{l}\text { This is a WordPress plugin to add } \\
\text { to your WordPress blog and use it } \\
\text { to collect donations from visitors. }\end{array}$ & $\begin{array}{l}\text { Online dona- } \\
\text { tion }\end{array}$ \\
\hline
\end{tabular}

Some crowdfunding platforms are more geared to developing products, others are about funding artistic endeavors, and still, others are ideally suited to nonprofits. The particular sites will collect all the money as it comes in; others will not collect it until the goal amount is reached.

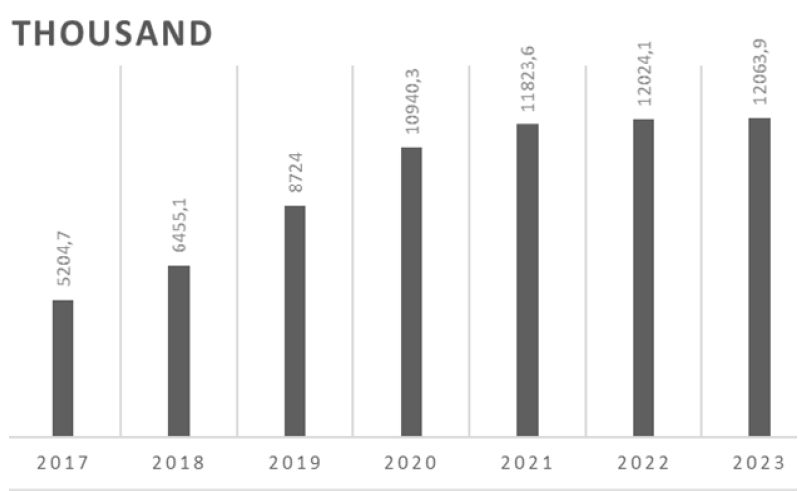

Fig. 4. Global crowdfunding campaigns (based on Statista [30]).

\subsection{Kickstarter: grandness of the phenomenon}

The Kickstarter platform was launched on April 28, 2009. However, its history goes back to 1713 , when Alexander Pope set out to translate 15,693 lines of ancient Greek poetry into English. In exchange for a shout-out in the acknowledgments, an early edition of the book, and the delight of assistance within bringing a creative work into the world, 750 subscribers pledged two gold guineas to support the author's effort before he put pen to paper.

In 2015, Kickstarter was reincorporated and achieved the status of a Benefit Corporation. Even though Benefit Corporations are for-profit companies, Kickstarter is considering the impact of funded decisions on society, not only shareholders. Radically, a positive impact on society becomes part of a Benefit Corporation's legally defined goals. The crowdfunding platform has its unique mission, vision, and goals, which also makes the basis for Kickstarter stockholders' activity (Table 2).

17 million people have backed a project, $\$ 4.7$ billion has been pledged, and 174634 projects have been successfully funded. However, Kickstarter statistic is changing daily (Figure 5).

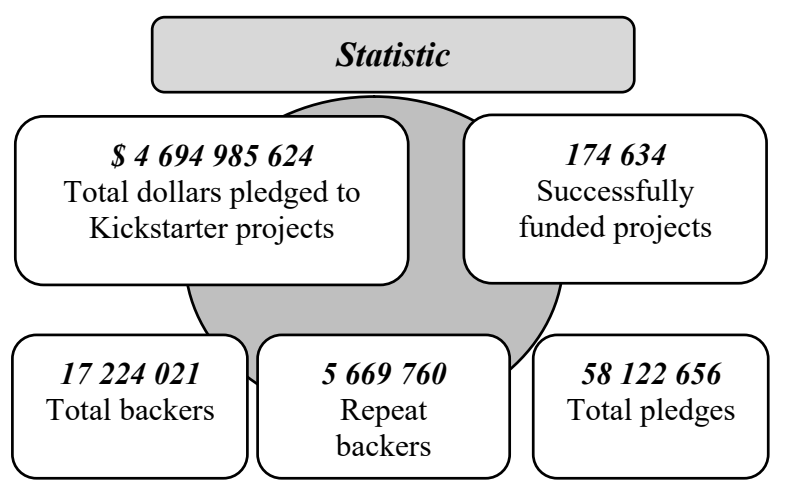

Fig. 5. Kickstarter statistic as of December 12, 2019.

Statistics are available for the site overall as well as each of the 15 project categories. Because the 
Kickstarter platform is represented as a Benefit Corporation, both creative and high-technology projects are financed on the platform (Table 3 ).

Table 2. Kickstarter platform phenomenon (based on Kickstarter statistics [31]).

\begin{tabular}{|c|c|}
\hline $\begin{array}{l}\text { Kickstarter } \\
\text { parameters }\end{array}$ & Overview \\
\hline $\begin{array}{l}\text { Kickstarter } \\
\text { mission }\end{array}$ & $\begin{array}{l}\text { The mission is to help bring creative projects } \\
\text { to life. }\end{array}$ \\
\hline $\begin{array}{l}\text { Kickstarter } \\
\text { goals }\end{array}$ & $\begin{array}{l}\text { 1. Kickstarter will create tools and resources } \\
\text { that help people bring their creative projects to } \\
\text { life, and that connect people around creative } \\
\text { projects and the creative process. } \\
\text { 2. Kickstarter will care for the health of its } \\
\text { ecosystem and integrity of its systems. } \\
\text { 3. Kickstarter will engage beyond its walls } \\
\text { with the greater issues and conversations } \\
\text { affecting artists and creators. }\end{array}$ \\
\hline $\begin{array}{l}\text { Kickstarter } \\
\text { vision }\end{array}$ & $\begin{array}{l}\text { The vision is for-profit companies support, } \\
\text { which activity aims to provide both economic } \\
\text { and social impact }\end{array}$ \\
\hline Community & $\begin{array}{l}\text { Kickstarter is an enormous global community } \\
\text { built around creativity and creative projects. } \\
\text { Over } 10 \text { million people, from every continent } \\
\text { on earth, have backed a Kickstarter project. }\end{array}$ \\
\hline $\begin{array}{l}\text { The main } \\
\text { stakeholders } \\
\text { groups }\end{array}$ & $\begin{array}{l}\text { Artists, musicians, filmmakers, designers, and } \\
\text { other creators }\end{array}$ \\
\hline $\begin{array}{l}\text { Kickstarter } \\
\text { team }\end{array}$ & $\begin{array}{l}\text { Independent, founder-controlled company of } \\
153 \text { people working together in an old pencil } \\
\text { factory in New York City. }\end{array}$ \\
\hline $\begin{array}{l}\text { Kickstarter } \\
\text { operations to } \\
\text { support } \\
\text { sustainability }\end{array}$ & $\begin{array}{l}\text { Kickstarter will seek to limit environmental } \\
\text { impact. It will invest in green infrastructure, } \\
\text { support green commuting methods, and factor } \\
\text { environmental impact when choosing vendors. } \\
\text { Additionally, Kickstarter will provide } \\
\text { recommendations and resources that help } \\
\text { creators make environmentally conscious } \\
\text { decisions on tasks, like shipping and } \\
\text { packaging, that are common to the use of its } \\
\text { services. }\end{array}$ \\
\hline $\begin{array}{l}\text { Financial } \\
\text { model }\end{array}$ & $\begin{array}{l}\text { If a project is successfully funded, Kickstarter } \\
\text { applies a } 5 \% \text { fee to the funds collected. All } \\
\text { pledges are processed securely by our third- } \\
\text { party payments partner, Stripe. These payment } \\
\text { processing fees work out to roughly } 3-5 \% \text {. If } \\
\text { the project does not reach its funding goal, } \\
\text { there are no fees. }\end{array}$ \\
\hline
\end{tabular}

However, the creative component of human development needs to expand a range of financial resources for their support due to the rather high risk of such kind of social investment. At the same time, the creative projects are the most successful on the Kickstarter platform (Table 4).

Thus, Kickstarter is a funding platform for creative projects - everything from films, games, and music to art, design, and technology. The available statistics and analytical researches show that in general Kickstarter projects tend to be successful (about $50 \%$ ) rather than fail (about $35 \%$ ) or get cancelled (about $8 \%$ ). Given the data provided on the official website, there is a difference among the Kickstarter project outcomes in particular areas. For instance, the highest successful implication is typical for projects in music $(82 \%)$, theatre $(63 \%)$, film and video (63\%). At the same time, nutrition, games and publishing have the lowest success rates (less than $50 \%$ for each group). Thereby, the Kickstarter database analysis confirms its role as the creative projects specialized platform.

Table 3. Kickstarter platform projects and financial support volumes.

\begin{tabular}{|l|c|c|c|c|c|c|}
\hline $\begin{array}{c}\text { Project } \\
\text { cate- } \\
\text { gory }\end{array}$ & $\begin{array}{c}\text { Laun- } \\
\text { ched }\end{array}$ & Total \$ & $\begin{array}{c}\text { Successful } \\
\text { \$ }\end{array}$ & Live \$ & Live & $\begin{array}{c}\text { Suc- } \\
\text { cess, } \\
\text { \% }\end{array}$ \\
\hline All & 478,806 & $4.82 \mathrm{~B}$ & $4.32 \mathrm{~B}$ & $41 \mathrm{M}$ & 3,866 & 37.57 \\
\hline Games & 50,909 & $1.21 \mathrm{~B}$ & $1.12 \mathrm{~B}$ & $14.25 \mathrm{M}$ & 659 & 40.39 \\
\hline Design & 40,361 & $1.09 \mathrm{~B}$ & $990.20 \mathrm{M}$ & $12.74 \mathrm{M}$ & 382 & 38.08 \\
\hline $\begin{array}{l}\text { Tech- } \\
\text { nology }\end{array}$ & 41,805 & $905.46 \mathrm{M}$ & $794.19 \mathrm{M}$ & $6.33 \mathrm{M}$ & 403 & 20.64 \\
\hline $\begin{array}{l}\text { Film \& } \\
\text { Video }\end{array}$ & 74,130 & $464.72 \mathrm{M}$ & $395.23 \mathrm{M}$ & $1.35 \mathrm{M}$ & 418 & 37.61 \\
\hline Music & 61,956 & $246.00 \mathrm{M}$ & $224.81 \mathrm{M}$ & $941.85 \mathrm{~K}$ & 290 & 50.00 \\
\hline $\begin{array}{l}\text { Fa- } \\
\text { shion }\end{array}$ & 31,100 & $184.16 \mathrm{M}$ & $161.50 \mathrm{M}$ & $832.13 \mathrm{~K}$ & 252 & 27.91 \\
\hline $\begin{array}{l}\text { Pub- } \\
\text { lishing }\end{array}$ & 49,261 & $176.84 \mathrm{M}$ & $155.33 \mathrm{M}$ & $967.09 \mathrm{~K}$ & 353 & 33.02 \\
\hline Food & 29,729 & $160.53 \mathrm{M}$ & $135.62 \mathrm{M}$ & $670.60 \mathrm{~K}$ & 209 & 25.19 \\
\hline Art & 38,130 & $126.72 \mathrm{M}$ & $112.95 \mathrm{M}$ & $1.04 \mathrm{M}$ & 430 & 44.02 \\
\hline Comics & 15,686 & $107.76 \mathrm{M}$ & $100.08 \mathrm{M}$ & $1.28 \mathrm{M}$ & 214 & 58.69 \\
\hline $\begin{array}{l}\text { Photo- } \\
\text { graphy }\end{array}$ & 12,307 & $48.06 \mathrm{M}$ & $42.19 \mathrm{M}$ & $129.52 \mathrm{~K}$ & 58 & 32.21 \\
\hline $\begin{array}{l}\text { Thea- } \\
\text { ter }\end{array}$ & 12,229 & $46.69 \mathrm{M}$ & $41.91 \mathrm{M}$ & 61,597 & 45 & 60.09 \\
\hline Crafts & 11,262 & $19.57 \mathrm{M}$ & $16.12 \mathrm{M}$ & $86.54 \mathrm{~K}$ & 97 & 25.04 \\
\hline $\begin{array}{l}\text { Jour- } \\
\text { nalism }\end{array}$ & 5,690 & $17.72 \mathrm{M}$ & $15.43 \mathrm{M}$ & 73,283 & 37 & 22.71 \\
\hline Dance & 4,251 & $14.77 \mathrm{M}$ & $13.71 \mathrm{M}$ & 40,838 & 19 & 61.84 \\
\hline
\end{tabular}

Table 4. Successful projects on the Kickstarter platform, projects.

\begin{tabular}{|l|c|c|c|c|c|c|}
\hline $\begin{array}{l}\text { Catego- } \\
\text { ry }\end{array}$ & $\begin{array}{c}< \\
\mathbf{\$ 1 0 0 0}\end{array}$ & $\begin{array}{c}\mathbf{\$ 1 0 0 0} \mathbf{9 9 9 9} \\
\mathbf{9 1 0 0 0 0}\end{array}$ & $\begin{array}{c}\mathbf{\$ 1 9 9 9 9} \\
\mathbf{\$ 2 0 0 0 0} \\
\mathbf{9 9 0 0 0}\end{array}$ & $+\mathbf{\$ 1 0 0 K}$ & $+\mathbf{\$ 1 M}$ \\
\hline All & 23,189 & 96,770 & 25,679 & 25,993 & 6,397 & 426 \\
\hline Music & 3,061 & 21,634 & 4,217 & 1,825 & 92 & 2 \\
\hline $\begin{array}{l}\text { Film \& } \\
\text { Video }\end{array}$ & 3,252 & 15,553 & 4,362 & 4,117 & 429 & 7 \\
\hline Games & 1,649 & 8,399 & 3,557 & 4,829 & 1,698 & 163 \\
\hline Art & 4,551 & 9,655 & 1,411 & 890 & 84 & 5 \\
\hline $\begin{array}{l}\text { Pub- } \\
\text { lishing }\end{array}$ & 2,345 & 9,964 & 2,181 & 1,537 & 124 & 0 \\
\hline Design & 1,061 & 4,994 & 2,641 & 4,643 & 1,774 & 112 \\
\hline Comics & 1,255 & 5,731 & 1,015 & 953 & 125 & 1 \\
\hline Fashion & 1,561 & 3,870 & 1,433 & 1,474 & 265 & 6 \\
\hline $\begin{array}{l}\text { Tech- } \\
\text { nology }\end{array}$ & 498 & 2,304 & 1,229 & 2,775 & 1,620 & 121 \\
\hline Food & 737 & 3,045 & 1,765 & 1,779 & 102 & 9 \\
\hline Theater & 1,043 & 5,312 & 644 & 303 & 19 & 0 \\
\hline $\begin{array}{l}\text { Photo- } \\
\text { graphy }\end{array}$ & 735 & 2,142 & 588 & 443 & 37 & 0 \\
\hline Crafts & 956 & 1,447 & 221 & 160 & 12 & 0 \\
\hline Dance & 239 & 2,046 & 253 & 78 & 1 & 0 \\
\hline $\begin{array}{l}\text { Journa- } \\
\text { lism }\end{array}$ & 246 & 674 & 162 & 187 & 15 & 0 \\
\hline
\end{tabular}




\subsection{Ukraine and Poland on the Kickstarter platform}

Ukraine and Poland are among the leaders in Eastern Europe on the Kickstarter platform. In particular, following the statistic on the number of projects, both countries are the leading ones (Figure 6).

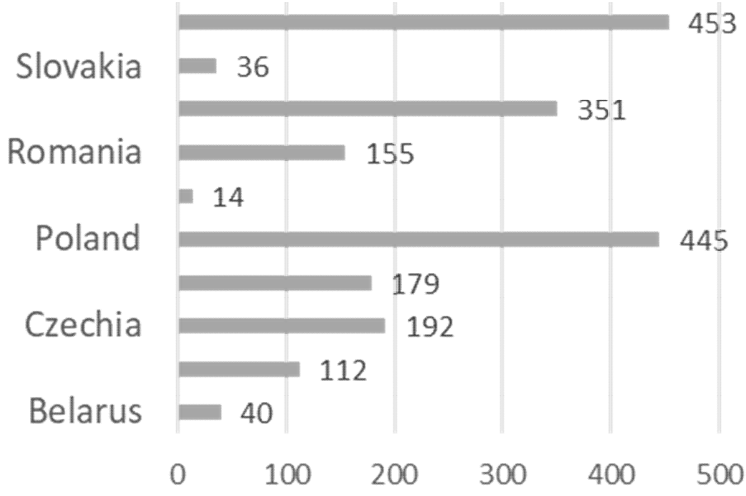

Fig. 6. The comparative analysis of projects number on Kickstarter, projects.

The same tendencies are defined for the average volumes of investment per one backer in these countries (Figure 7).

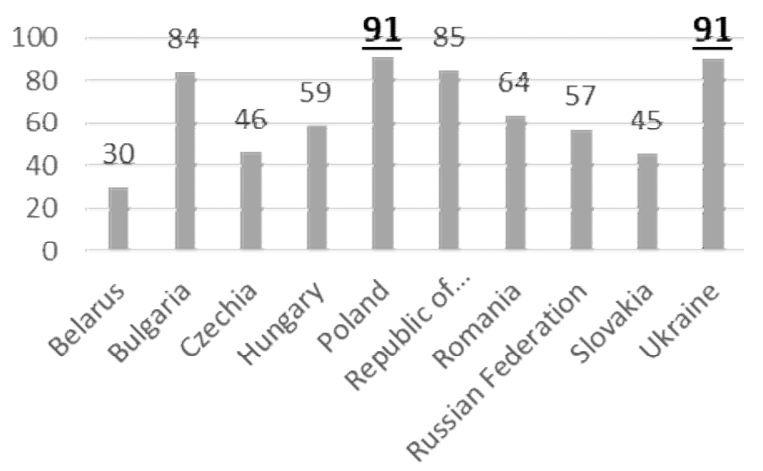

Fig. 7. The comparative analysis of the average volumes of investment per one backer on Kickstarter, USD.

Thus, Ukrainian and Polish creative projects gather the main part of total funding (Figure 8).

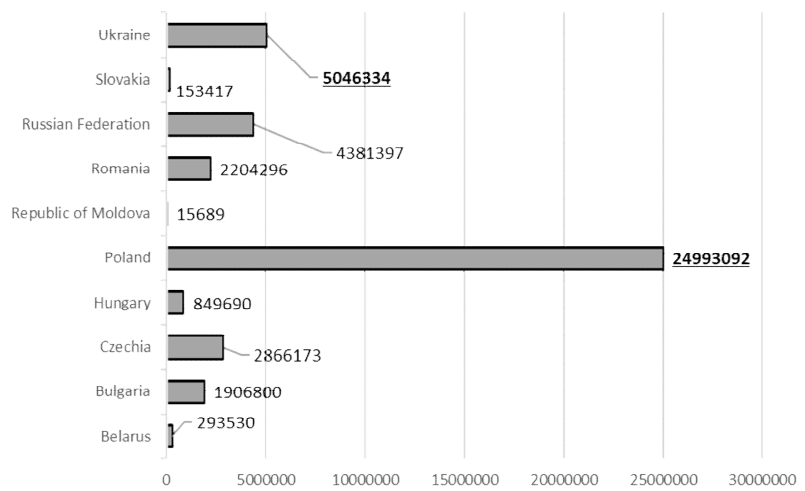

Fig. 8. The comparative analysis of total funds raised on Kickstarter, USD.

At the same time, an important indicator of crowdfunding financing effectiveness in a particular country is the share of successfully funded projects. The following data have been collected to analyze the aboveand below-mention indicators of Ukrainian and Polish creative projects Kickstarter funding, including timeframe of ten years $(2009-2019)$; total number of industries: 83 ; total number of projects and project essence: 898; stated goal and raised funds in USD; the share of reaching goals; number of backers; project campaign start/end/duration; project status; total funds raised in USD; successful projects share and funding volume (Figure 9).

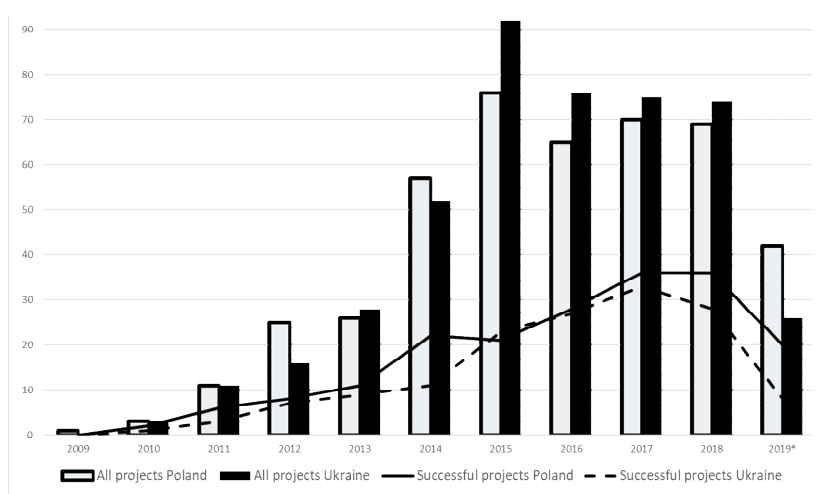

Fig. 9. The successful Ukrainian and Polish creative projects share and trends on Kickstarter platform, \% (black for Ukraine; white for Poland).

Ukraine is slightly overtaking Poland by the number of announced projects, but Polish projects are more successful and more often reach established investment goals (Figure 10).

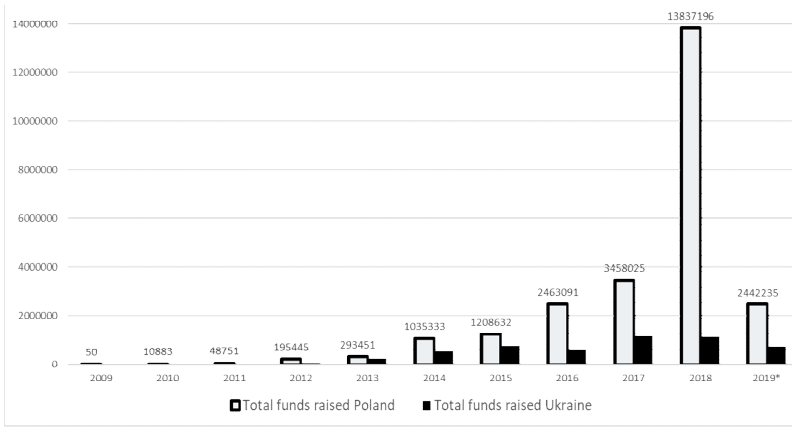

Fig. 10. Ukrainian and Polish creative project financing trends on Kickstarter, projects (black for Ukraine; white for Poland).

Thereby, both countries are the leaders on the Kickstarter platform. However, Polish creative projects seem to be more effective due to the different levels of effort for crowdfunding financing concentration.

\subsection{Creative projects in Ukraine and Poland: concentration of efforts for crowdfunding financing (Kickstarter experience)}

Ukrainian and Polish creative projects are among leaders on the Kickstarter platform following both qualities' and quantities' indicators. However, there is a different approach, concerning countries profile industrial structures (Figure 11). 


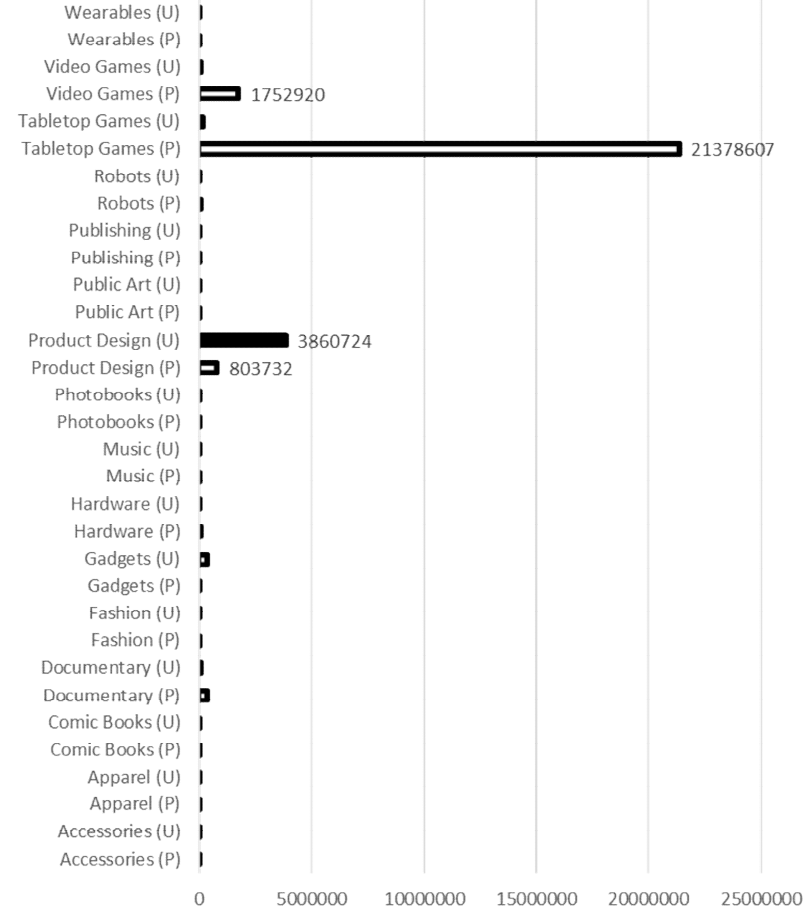

Fig. 11. Country profiles: industries, projects (black for Ukraine; white for Poland).

The country Kickstarter profile of Poland is defined as a concentration of intangible intellectual products (Table 5).

Table 5. Industries: concentration of efforts in Poland.

\begin{tabular}{|r|l|c|c|r|}
\hline & Industry & All projects & $\begin{array}{c}\text { Successful } \\
\text { projects }\end{array}$ & $\begin{array}{c}\text { Total funds } \\
\text { raised }\end{array}$ \\
\hline 1 & Tabletop Games & 122 & 83 & 21378607 \\
\hline 2 & Video Games & 61 & 31 & 1752920 \\
\hline 3 & Product Design & 17 & 6 & 803732 \\
\hline 4 & Documentary & 38 & 13 & 362596 \\
\hline 5 & Robots & 2 & 1 & 76372 \\
\hline 6 & Hardware & 4 & 1 & 67551 \\
\hline 7 & Wearables & 2 & 2 & 58096 \\
\hline 8 & Music & 5 & 3 & 41904 \\
\hline 9 & Comic Books & 2 & 2 & 38109 \\
\hline 10 & Public Art & 4 & 1 & 33442 \\
\hline
\end{tabular}

At the same time, the country Kickstarter profile of Ukraine is defined as a concentration of tangible physical goods (Table 6).

The chosen dataset provides the information on success rate of Ukrainian and Polish creative project on Kickstarter. In particular, in 2019 more than $30 \%$ of Ukrainian and more than $40 \%$ of Polish creative projects were successful. An average percent of project goal achievement is about $150 \%$ and $220 \%$ accordingly. The above-mentioned tendencies are reflected within the most successful Ukrainian and Polish creative projects on the Kickstarter platform (Figure 12).

A successful Kickstarter crowdfunding campaign duration varies from 7 to 90 days in Ukraine and from 14 to 90 days in Poland. The number of people who supported the creative project on Kickstarter varies from
2 to 6110 person in Ukraine and from 5 to 41939 person in Poland.

Table 6. Industries: concentration of efforts in Ukraine.

\begin{tabular}{|r|l|r|r|r|}
\hline & Industry & All projects & $\begin{array}{c}\text { Successful } \\
\text { projects }\end{array}$ & $\begin{array}{c}\text { Total funds } \\
\text { raised }\end{array}$ \\
\hline 1 & Product Design & 141 & 71 & 3860724 \\
\hline 2 & Gadgets & 12 & 7 & 359461 \\
\hline 3 & Tabletop Games & 13 & 5 & 186856 \\
\hline 4 & Documentary & 30 & 5 & 84755 \\
\hline 5 & Video Games & 19 & 3 & 58254 \\
\hline 6 & Accessories & 13 & 5 & 39475 \\
\hline 7 & Photobooks & 4 & 1 & 36393 \\
\hline 8 & Apparel & 8 & 2 & 32094 \\
\hline 9 & Publishing & 6 & 2 & 31866 \\
\hline 10 & Fashion & 10 & 4 & 27466 \\
\hline
\end{tabular}

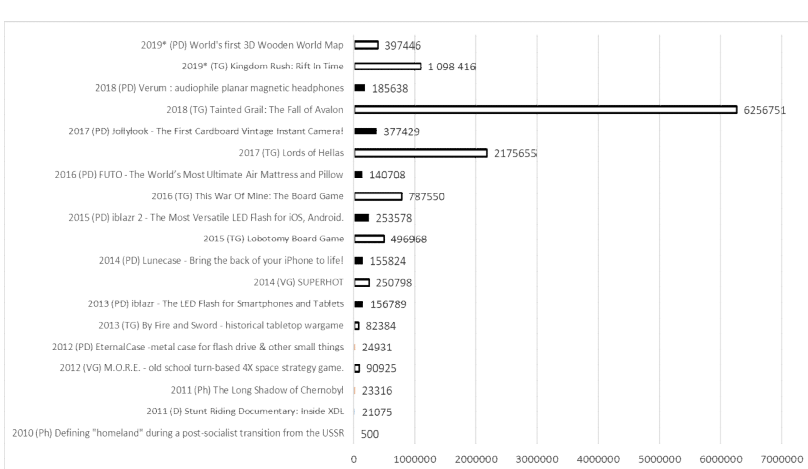

Fig. 12. The most successful Kickstarter projects: Ukraine vs Poland, USD (black for Ukraine; white for Poland).

The smallest successful Ukrainian Kickstarter project is "Learn English with 850 Basic English words". Two person donated 50 USD during 7 days to achieve the project goal, namely to shoot a short movie in English, using dictionary words Basic English 850. The creator already had the necessary equipment, a small studio, and students who wanted to play in film. Thereby, the crowdfunding campaign played rather the role of advertisement, motivation for Ukrainian people to learn English.

The Ukrainian creative project on Kickstarter that attracted the widest audience was "Jollylook - The First Cardboard Vintage Instant Camera!". 6110 person donated 377429 USD instead of 15000 USD during 31 days (in April 2017) to produce a simple fold out camera for analog snapshots, made entirely from recycled paper and cardboard. As the result of crowdfunding campaign on Kickstarter, about 1043 cameras were sold on online pre-order for 46.958 USD as of November 2018. In December 2019, the Camera is represented at Amazon with 4 ranking. There are more than 160 posts from all over the world on Camera features only on Instagram. There are also many product video reviews on YouTube and Facebook with positive assessment of Camera design and images quality.

The longest Ukrainian crowdfunding campaign duration was 90 days to raise funding for "The Long Shadow of Chernobyl" project. The project goal was to raise awareness of the Chernobyl Nuclear Disaster 25 
years later through a retrospective photo book by Gerd Ludwig. The Kickstarter campaign was rather successful. The project initiator gathered twice more funding from 435 donors. Gerd Ludwig spent about 5 weeks in Chernobyl region, photographing deep inside the reactor. One year later, the images were first exhibited at the EBRD headquarters in London, helping to raise the addition 1.5 billion dollars needed to build the New Safe Confinement and safely deconstruct the ailing Chernobyl shelter. The project is still active nowadays. The photo book is represented on Amazon.

The shortest Polish crowdfunding campaign lasted during 11 days to assist Violet \& Myo within their Eastern Europe tour, namely to cover their train fare. As the result, Violet \& Myo achieved their goal.

The most successful Polish crowdfunding campaign lasted 23 days and enabled to gather 6199036 USD out of desirable 50194 USD (41939 backers) for "Tainted Grail: The Fall of Avalon" project. This adventure, survival cooperation Board Game set in unique grim world inspired by Arthurian Legends. Currently, the game ranking is 8.8 out of 10 (nearly $1 \mathrm{~K}$ comments).

The longest Kickstarter Polish crowdfunding campaigns lasted 90 days (a screenplay "Mike \& Zack's Righteous Journey" and a journalist research "Life In the Shadow of Auschwitz"). The projects were successfully funded for more than $100 \%$.

Despite available theoretical researches on crowdfunding functionality, there is no approved methodology to estimate the concentration of efforts for crowdfunding financing. Thereby, to examine this issue the concentration ratio (CR3 and CR10) methodology was applied within the current research (Table 7). The table shows that the concentration ratio, based on the three and ten leading branches, indicated a higher level of effort polish projects' concentration on the Kickstarter platform.

Table 7. The concentration of efforts indicators for Ukraine and Poland.

\begin{tabular}{|c|c|c|c|}
\hline Poland & $\begin{array}{c}\text { All projects } \\
445\end{array}$ & $\begin{array}{c}\text { Successful projects } \\
190\end{array}$ & $\begin{array}{c}\text { Total funds } \\
24993092\end{array}$ \\
\hline \multicolumn{4}{|c|}{ Concentration of efforts indicators } \\
\hline CR3-Index & 44.94 & 63.16 & 95.77 \\
\hline CR10-Index & 57.75 & 75.26 & 98.48 \\
\hline \multicolumn{4}{|c|}{} \\
\hline Ukraine & $\begin{array}{c}\text { All projects } \\
453\end{array}$ & $\begin{array}{c}\text { Successful projects } \\
150\end{array}$ & $\begin{array}{c}\text { Total funds } \\
5046334\end{array}$ \\
\hline \multicolumn{4}{|c|}{ Concentration of efforts indicators } \\
\hline CR3-Index & 36.64 & 55.33 & 87.33 \\
\hline CR10-Index & 56.51 & 70.00 & 92.94 \\
\hline
\end{tabular}

Thus, despite the equal quantity and volumes of crowdfunding financing in Poland and Ukraine, Polish fundraisers pay more attention to intangible intellectual products. This causes the highest concentration of efforts, developing creative projects in Poland.

\section{Conclusions}

Given all that has been mentioned so far, one may state that crowdfunding financing is getting growing effectiveness within creative project implementation. The primary analytical research of Kickstarter statistics shows the increasing trends of total funds raised and all projects financed both in Ukraine and Poland.

At the same time, the study results show that the global digital platform (Kickstarter for creative industries) is a reflection a reflection of interrelations between intangible and tangible values in economies. Ukraine and Poland were chosen for comparison because of their common geographic location, close and growing economic cooperation. At the same time, the Polish GDP per capita exceeds the corresponding Ukrainian indicator more than tenfold. However, Polish creative project financing trends on Kickstarter are more successful than Ukrainian ones.

For measuring the concentration of efforts for comparing countries, the Concentration Ratio (CR), proposed by Bain to analyse the market share, was successfully applied with the following modifications: 1) not the share of the largest firms in industry revenue, but the share of the largest industries in the general market; 2) not a market for products, but a market for resources (namely, crowdfunding financing). The proposed "Three-Branch Concentration Ratio" and "The Ten-Branch Concentration Ratio" measure the total market share of the three / ten largest industries on the Kickstarter platform accordingly.

The results of the study revealed high rates of concentration of efforts of Ukrainian projects in creative industries that commercialize tangible physical goods: Product Design (141 projects) and Gadgets (12 projects). At the same time, the main concentration of efforts of Polish creative projects is observed in the field of intangible intellectual products: Tabletop Games (122 projects) and Video Games (61 projects).

The same trend is confirmed by the industry affiliation of the most successful projects: 1) the most successful Ukrainian project is "World's first 3D Wooden World Map" (Industry: Product Design); 2) the most successful Polish project is "The Fall of Avalon" (Industry: Tabletop Games).

There is an urgent need to concentrate more efforts on the crowdfunding process in Ukraine. Thereby, the study results of the can be used by the Ministry of Economy of Ukraine that provides organizational and financial support for creative innovative projects in part of crowdfunding platform access stimulation.

In particular, the Ukrainian crowdfunding stakeholders tend to pay attention on the following activities:

- stimulating the development of crowdfunding research in the works of Ukrainian scientists;

- creation of a centralized system of informing the national business entities and investors regarding the possibility of online cooperation;

- intensification of cooperation between public and private backers, who are ready to finance creative projects.

The essence of crowdfunding is both applied and theoretical question. Thus, the potential crowdfunding stakeholders pay attention to the factors of successful crowdfunding campaign, including: 
- ability to gather a network of enthusiastic stakeholders, who will assist at the initial stage of crowdfunding campaign;

- provide an effective system for stakeholders' stimulation;

- provide a serious business plan and project clear explanation for future stakeholders;

- demonstrate your previous achievements and professional skills;

- provide an effective video pitch, keep it short and concise;

- study of online audience needs.

Despite there is already a measure of researches on crowdfunding results and functions, experts still have a lack of information on some applied aspects, including:

- a measure of long-term results from crowdfunding financing;

- lack of information on successful crowdfunding campaign principles;

- lack of crowdfunding statistic both on global and national levels.

Thereby, there is a need for further crowdfunding research, considering its practical implication within modern society. In particular, in relation to other countries, these studies should be applied with caution due to the national economies' peculiarities. More extensive study is required. Thereby, this is the subject for future researches.

\section{References}

1. K. Manchanda, P. Muralidharan, Crowdfunding: a new paradigm in startup financing, in Global Conference on Business and Finance Proceedings 2014

2. T.H. Allison, B.C. Davis, J.W. Webb, J.C. Short, Persuasion in crowdfunding: An elaboration likelihood model of crowdfunding performance. Journal of Business Venturing 32(6) (2017)

3. B. Glencorse, Crowdfunding development aid would direct funds where they are needed most. Financing for development aid (2016), https:/www.theguardian.com/globaldevelopment/2016/sep/13/crowdfundingdevelopment-aid-funds-globalgiving-kickstarter. Accessed 21 Dec 2019

4. D.C. Brabham, How crowdfunding discourse threatens public arts. New Media \& Society 19(7) (2017)

5. B. Boeuf, J. Darveau, R. Legoux, Financing Creativity: Crowdfunding as a New Approach for Theatre Projects. International Journal of Arts Management 16(3) (2014)

6. M.G. Colombo, C. Franzoni, C. Rossi-Lamastra, Internal Social Capital and the Attraction of Early Contributions in Crowdfunding. Entrepreneurship Theory and Practice, 39(1) (2015)

7. M. Farnel, Kickstarting trans*: The crowdfunding of gender/sexual reassignment surgeries. New Media \& Society 17(2) (2015)
8. M. Barbi, M. Bigelli, Crowdfunding practices in and outside the US. Research in International Business and Finance 42 (2017)

9. J.H. Ganatra, When a kickstarter stops: exploring failures and regulatory frameworks for the rewardsbased crowdfunding industry. Rutgers University Law Review 68(3) (2016)

10. infoDev, Crowdfundinges potential for the developing world, Finance and Private Sector Development Department (World Bank, Washington, 2013)

11. G. Rabinowitz, A. Prizzon, Financing for development Lessons from Development Progress case studies (Overseas Development Institute, London, 2015)

12. S. Al-Samarrai, Financing primary education for all: Public expenditure and education outcomes in Africa (Institute of Development Studies, Brighton, 2003)

13. C. Arndt, S. Jones, F. Tarp, Aid effectiveness: Opening the black box. Working Paper 2011/44. World Institute for Development Economics Research 44 (2011)

14. F. Gebregziabher, M. Niño-Zarazúa, Social spending and aggregate welfare in developing and transition economies. UNU-WIDER Working Paper 082 (2014)

15. G. Le Bon, The Crowd: a Study of the Popular Mind (T. Fisher Unwin, London, 1895)

16. K. De Buysere, O. Gajda, R. Kleverlaan, D. Marom. A Framework for European Crowdfunding, 1st edn (European Crowdfunding Network, 2012)

17. Iu. Gernego, Crowdfunding: the worldwide conditions and prospects for usage in Ukraine, Actual Problem of Economics 12(174), (2015)

18. D. Hengchen, J.Z. Dennis, Prosocial Goal Pursuit in Crowdfunding: Evidence from Kickstarter. Journal of Marketing Research 56, 3 (2019)

19. A. Kindler, M. Golosovsky, S. Sorin, Early Prediction of the Outcome of Kickstarter Campaigns: Is the Success Due to Virality? Palgrave Communications 5, 1 (2019)

20. K. Dahlhausen, L. Bethany, J. Krebs, V. Watters, H. Holly Ganz, Crowdfunding Campaigns Help Researchers Launch Projects and Generate Outreach. Journal of Microbiology \& Biology 17, 1 (2016)

21. J. Bain, Industrial organization (J. Wiley, New York, 1959)

22. L. Batsenko, R. Galenin, Innovative development of human resources in new economic conditions. Visnyk naukovych prats LNAU 16/1 (2011)

23. S. Mishchenko, A. Sokolova, Institutional support of fundraising in Ukraine and prospects for development. Naukovyy visnyk Poltavskoho universytetu ekonomiky i torhivli 1(56) (2013) 
24. International Development Association (IDA). The World Bank's fund for the poorest, http://www.worldbank.org/ida/. Accessed 21 Dec 2019

25. International Finance Corporation. The World Bank Group,

http://www.ifc.org/wps/wcm/connect/corp_ext_cont ent/ifc_external_corporate_site/home. Accessed 21 Dec 2019

26. Multilateral Investment Guarantee Agency. The World Bank Group, http://www.miga.org/. Accessed 21 Dec 2019

27. The International Centre for Settlement of Investment Disputes. The World Bank Group, www.worldbank.org/icsid. Accessed 21 Dec 2019

28. T. Kozhukhova, World Bank Financing for Development Projects in Ukraine. Scientific Bulletin of the International Humanities University. Series: Economics and Management 15 (2016)

29. Iu. Gernego, O. Dyba, L. Petrenko, Determinants of innovative activities conserning socio-economic growth. Financial and credit activity: problems of theory and practice $\mathbf{3}$ (2019)

30. Statista, https://www.statista.com/outlook/335/100/c rowdfunding/worldwide. Accessed 21 Dec 2019

31. Kickstarter, https://www.kickstarter.com. Accessed 21 Dec 2019 